\title{
KOMPETENSI PERAWAT DALAM MERAWAT PASIEN GANGGUAN JIWA
} (Nursing Competencies in Taking Care Patient with Mental Disorders)

\author{
Ah. Yusuf, Rizki Fitryasari, Hanik Endang Nihayati, Rr. Dian Tristiana \\ Fakultas Keperawatan Universitas AirlanggaKampus C Unair Jl. Mulyorejo Surabaya \\ Email: ah-yusuf@fkp.unair.ac.id
}

\begin{abstract}
ABSTRAK
Pendahuluan: Kompetensi yang dimiliki perawat dapat menjadi sebuah kemampuan yang baik apabila didukung oleh persepsi perawat yang positif tentang kompetensi itu sendiri. Penelitian ini bertujuan untuk menggambarkan kompetensi perawat dalam merawat pasien gangguan jiwa dan hambatan yang ditemukan dalam pelaksanaan kompetensi tersebut. Metode: Penelitian menggunakan desain kualitatif dengan pendekatan fenomenologi deskriptif. Populasi penelitian adalah perawat yang bekerja di Rumah Sakit Jiwa, sampel penelitian diperoleh dengan purposive sampling, Partisipan terdiri dari 17 perawat yang bekerja di dua Rumah Sakit Jiwa terbesar di Jawa Timur. Metode pengumpulan data menggunakan wawancara mendalam dan focus group discussion $(F G D)$. Alat pengumpulan data yang digunakan adalah media player (MP-4), pedoman FGD dan catatan lapangan. Data diolah dengan analisis tematik menurut Colaizzi. Hasil: Hasil penelitian meliputi 8 tema, yaitu bahwa persepsi perawat tentang kompetensi perawat RSJ dalam merawat pasien gangguan jiwa adalah melaksanakan asuhan keperawatan, melaksanakan Standar Prosedur Operasional (SPO) di ruangan dan melaksanakan terapi modalitas keperawatan jiwa. Sementara perawat menjumpai hambatan saat mengaplikasikan kompetensi dalam pelaksanaan dokumentasi keperawatan, keterbatasan fasilitas, kurang efektifnya pelakasanaan manajemen ruangan, keterbatasan sumber daya manusia serta kondisi pasien yang dirawat. Diskusi: Temuan penelitian dapat dimanfaatkan oleh perawat sebagai bahan untuk mengembangkan desain format dokumentasi pasien gangguan jiwa yang lebih efektif dan diharapkan manajemen rumah sakit untuk lebih memperhatikan aspek pengarahan dan supervisi dalam pelaksanaan kompetensi perawat. Penelitian yang disarankan untuk dikembangkan berdasarkan temuan penelitian adalah melihat hubungan pelaksanaan supervisi keperawatan terhadap peningkatan kinerja dan kepuasan perawat
\end{abstract}

Kata kunci : kompetensi, perawat, gangguan jiwa.

\begin{abstract}
Introduction: Competences of the nurse can be a good ability when supported with a positive perception of nurses about the competence itself. This study describe the nurse competencies in taking care patients with mental disorders and barriers in the implementation of these competencies. Methods: This study design used qualitative descriptive phenomenology. Population was nurse who worked at the Mental Hospital. Participants were 17 nurses from two Mental Hospital in East Java which obtained by purposive sampling. Data was collected by indepth interview and focus group discussion (FGD). Equipment tools used media player, FGD guidelines and field notes. The data were analyzed by thematically analysis based Colaizzi. Result: The results produce eight themes. The nurse's perception of competence in caring for patients with mental disorders are implementing nursing care, Standard Procedures Operational (SPO) and nursing modality therapy. While nurses encounter obstacles when applying competence in the implementation of nursing documentation, limited facilities, the lack of effectiveness management system, limited human resource and the condition of the patient. Discussion: The findings of this study can be used by nurses as a material to develop documentation formats more effectively and hospital management are expected to pay more attention to aspects of the guidance and supervision of the implementation of competence. Research suggested based on the findings is to analyze the relationship between supervision and nurse's performance and satisfaction
\end{abstract}

Keyword: Nurse, Competencies, Mental Disorder

\section{PENDAHULUAN}

Pelayanan keperawatan merupakan bagian tidak terpisahkan dari pelayanan kesehatan yang berperan dalam mencapai derajat kesehatan yang optimal pada tatanan individu, keluarga dan masyarakat. Pelayanan keperawatan di rumah sakit sebagai ujung tombak yang mampu menjadi daya ungkit yang besar dalam upaya pembagunan kesehatan (Depkes RI, 1999). Profesionalisme perawat, khususnya pelayanan keperawatan di rumah sakit dimulai dari komitmen dan internalisasi perawat terhadap profesi keperawatan itu sendiri. Perawat dituntut memiliki kemampuan intelektual, teknikal, dan interpersonal serta bertanggung jawab terhadap tindakan yang dilakukan.

Kompetensi perawat berhubungan erat dengan kemampuan dan motivasi kerja yang kuat dalam memberikan pelayanan. Kompetensi yang dimiliki perawat, tercermin pada pelaksanaan tugas keperawatan dalam pelayanan kepada pasien, tidak terkecuali pada perawat di Rumah Sakit Jiwa (RSJ). Kompetensi perawat jiwa dapat diperoleh melalui proses pendidikan formal maupun pelatihan dalam lingkup kesehatan jiwa. Kompetensi yang dimiliki seoarang perawat 
dapat menjadi sebuah kemampuan yang maksimal apabila didukung dengan persepsi perawat yang positif tentang kompetensi itu sendiri.

Hasil wawancara pada beberapa perawat di RSJ di Jawa Timur terkait pandangan perawat tentang profesi dan kemampuan kerja perawat di RSJ menunjukkan keanekaragaman fakta. Ada yang menyampaikan bahwa selama ini perawat masih berpikiran sebagai pembantu dokter, tidak jelas bidang garapnya, kurang percaya diri bila berhadapan dengan profesi kesehatan yang lain, belum sepenuh hati dalam menjalankan aktivitas keperawatan, belum optimal berinteraksi dengan pasien,terlalu banyak tugas dokumentasi dan masih belum memahami secara tuntas pemberian asuhan keperawatan secara holistik. Sementara disisi lain ada perawat yang memiliki pandangan positif bahwa menjadi perawat di RSJ merupakan tugas mulia dan merasa senang ketika pasien yang dirawat mampu mandiri dan diijinkan pulang dari RSJ. Pihak RSJ juga sangat menyadari keberagaman pandangan perawat tersebut dan sudah berupaya untuk meminimalkan dampak yang terjadi terutama terhadap kinerja perawat. Pihak manajemen RSJ sering melakukan pertemuan rutin dengan perawat, banyak berdiskusi dengan jajaran pimpinan RSJ dan mengirim perawat untuk mengikuti pelatihan serta menerapakan sistem reward.

Fenomena dan fakta terhadap profesi perawat tersebut merupakan permasalahan yang menarik untuk ditelusuri, sehingga peneliti ingin mendapatkan gambaran secara kualitatif terkait persepsi perawat RSJ terhadap kompetensi merawat pasien gangguan jiwadan hambatan yang dirasakan selama mengaplikasikan kompetensi tersebut.

\section{BAHAN DAN METODE}

Penelitian menggunakan desain kualitatif dengan pendekatan fenomenologi deskriptif untuk menggambarkan kompetensi perawat dalam pasien gangguan jiwa. Kompetensi perawat diukur berdasarkan persepsi perawat RSJ tentang kinerja yang harus dimiliki selama bekerja di RSJ. Populasi penelitian adalah perawat yang bekerja di RSJ Menur dan Lawang, pemilihan sampel menggunakan purposive sampling yaitu metode pemilihan sampel yang sesuai dengan tujuan penelitian. Seluruh partisipan penelitian adalah perawat yang bekerja di RSJ dengan kriteria: telah bekerja minimal 1 tahun, berpendidikan minimal DIII keperawatan, mampu berkomunikasi dengan baik serta sehat fisik dan mental saat dilakukan pengambilan data.

Partisipan terdiri dari 10 perawat dari RSJ Menur dan 7 perawat dari RSJ Lawang. Metode pengumpulan data yang digunakan adalah indepth interview dan focus group discussion ( $F G D)$. Alat pengumpulan data yang digunakan adalah Media Player (MP-4), pedoman wawancara, catatan lapangan dan diri peneliti. FGD dilaksanakan menjadi dua kelompok, yaitu kelompok perawat RSJ Menur dan kelompok RSJ Lawang di tempat dan waktu yang berbeda dengan menggunakan stimulasi pertanyaan yang sama.Data yang diperoleh dari hasil FGD dan field note dibuat transkrip verbatim selanjutnya proses analisa dalam penelitian ini menggunakan sembilan langkah menurut Colaizzi.

\section{HASIL}

Peneliti mengidentifikasi 8 tema sebagai hasil penelitian. Proses pemunculan tema tersebut diuraikan berdasarkan tujuan penelitian.Tujuan penelitian pertama adalah persepsi perawat tentang kompetensi perawat dalam merawat pasien gangguan jiwa, terdiri dari 3 tema, yaitu melaksanakan asuhan keperawatan, melaksanakan standar prosedur operasional (SPO) di ruangan dan melaksanakan terapi modalitas keperawatan jiwa. Tujuan penelitian 2 adalah hambatan yang ditemui dalam mengaplikasikan kompetensi sebagai perawat jiwa meliputi 5 tema, yaitu hambatan dalam pelaksanaan dokumentasi keperawatan, fasilitas yang terbatas, kurang efektifnya pelakasanaan manajemen di ruangan, kondisi sumber daya manusia yang dimiliki serta kondisi pasien yang dirawat.

\section{Persepsi tentang kompetensi perawat dalam merawat pasien gangguan jiwa}

\section{Tema 1. Memberikan asuhan keperawatan jiwa}

Memberikan asuhan keperawatan jiwa kepada pasien merupakan kompetensi yang dilakukan perawat RSJ terdiri dari tahapan asuhan keperawatan dan format dokumentasi askep. Tahapan dalam memberikan asuhan keperawatan meliputi pengkajian, perencanaan, implementasi dan evaluasi. 
evaluasi...."

“...mulai dari pengkajian sampai

“..asesmen sampai evaluasi....”

“...tahapnya pengkajian, perencanaan, implementasi dan evaluasi"

Pengkajian yang dilakukan dibedakan berdasarkan lokasi pasien dirawat, seperti pengkajian untuk pasien gangguan jiwa dewasa, NAPZA, anak atau geriatri.

“..ada format asesmen awal...asesmen dewasa...poli dan IGD.."

“...asesmen unit khusus seperti NAPZA, anak remaja, geriatri..."

Aspek yang dikaji meliputi alasan masuk, predisposisi, presipitasi, psikososial, status mental, mekanisme koping dan kebutuhan persiapan pulang. Seperti yang dinyatakan oleh informan di bawah ini.

"...dikaji dulu alasan masuk, predisposisi, psikososial, status mental, kebutuhan pulang, persiapan pulang..."

"...anamnese status mentalnya dulu ...."

Perencanan asuhan keperawatan dilakukan secara manual berdasarkan 10 Standar Asuhan Keperawatan yang meliputi masalah keperawatan Halusinasi, Waham, Isolasi Sosial, Harga Diri Rendah, Resiko Bunuh Diri, Perilaku Kekerasan, Defisit perawatan Diri: Mandi, Makan, Eliminasi, Berhias. Sementara di RSJ Lawang telah dilakukan sistem komputerisasi khususnya untuk di bagian rawat jalan.

“...sepuluh diagnosa keperawatan....”

“......sepuluh SAK....”

“...sistem online untuk IGD (NIC NOC)..."

Implementasi yang dilakukan menggunakan pendekatan strategi pelaksanaan yang dilaksanakan sesuai dengan perencanaan yang telah di susun. Evaluasi asuhan keperawatan dilaksanakan dengan membuat catatan perkembangan setiap shift yang diisi oleh perawat pelaksana dengan format SOAP, sementara perawat yang berperan sebagai ketua tim akan melakukan evaluasi berdasarkan catatan perkembangan ke catatan terintergasi dengan format SBAR.

“....CPPT diisi dalam bentuk pakem yaitu SOAP....."

“....kita pakai SOAP ...."

“....untuk komunikasi antardisiplin diisi katim $(S B A R) \ldots ”$

Format yang digunakan dalam melakukan asuhan keperawatan di RSJ menur maupun Lawang menggunakan format standar

yang telah di modifikasi dan disesuaikan dengan kebutuhan akreditasi rumah sakit. Beberapa jenis dokumentasi yang dikembangkan meliputi catatan perkembangan, catatan terintegrasi dan pengkajian resiko khususnya pada pasien dengan perilaku kekerasan. Cara pengisian format pengkajian dan intervensi juga mengalami modifikasi menjadi lebih sederhana dengan model checklist.

$$
\begin{aligned}
& \text { “....catatan perkembangan ...." } \\
& \text { ".......ppt ..." }
\end{aligned}
$$

\section{Tema 2 Melaksanakan Standar Prosedur Operasional (SPO)}

Perawat di RSJ menjalankan sejumlah SPO dalam merawat pasien gangguan jiwa. Beberapa jenis SPO menjadi wajib untuk dipahami dan dijalankan seluruh perawat melalui proses sosialisasi secara bertahap dari kepala ruangan ke perawat ruangan. SPO yang sudah tersedia meliputi SPO tentang pengisian format dokumentasi keperawatan dan ditambahkan SPO sesuai dengan kebutuhan akreditasi rumah sakit dan saat ini sedang dikembangkan SPO untuk keamanan pasien dan perawat.

“...Standar operasional prosedur untuk askep sudah ada ..." rutin..."

“...SPO tersosialisasi rutin setiap rapat

\section{Tema 3 Melakukan terapi modalitas keperawatan jiwa.}

Kompetensi melaksanakan terapi modalitas keperawatan disampaikan berdasarkan jenis, pelaksana, waktu, fasilitas, tempat dan metode. Jenis yang paling sering dilaksanakan adalah Terapi Aktifitas Kelompok (TAK) dengan berbagai topik dan Pendidikan Kesehatan Keluarga di Rumah Sakit (PKRS) dan di masyarakat.

$$
\begin{gathered}
\text { “...berjalan rutin }(T A K) . . . " \\
\text { “...TAK rutin..." } \\
\text { “...pendidikan ke keluarga sesuai } S P \\
\text { (Obat)..." }
\end{gathered}
$$

Kedua jenis terapi modalitas tersebut dilakanakan baik oleh perawat ruangan maupun mahasiswa perawat yang telah terjadwal secara rutin. Fasilitas pendukung untuk kedua terapi modalitasi ini sudah cukup memadai seperti adanya SPO, format dokumentasi, leaflet dan alat terapi. TAK dilaksanakan di ruangan maupun ruang rehabilitasi, sementara PKRS dilakukan di 
ruang yang terdapat keluarga diijinkan untuk menunggu seperti rawat jalan, ruang akut dan juga di lingkungan masyarakat yang menjadi wilayah kerja RSJ. Metode yang dikembangkan dalam pemberian terapi modalitas berdasarkan tujuan, modifikasi cara, tahapan dan bentuk terapi. TAK dapat diberikan dengan tujuan menciptakan lingkungan yang terapeutik atau mengajarkan life skill pada pasien, sehingga bentuk kegiatan TAK di modifikasi untuk mencapai tujuan dan diberikan bertahap sesuai dengan kemampuan yang dicapai oleh pasien.

\section{Persepsi perawat RSJ tentang hambatan yang dijumpai selama menerapkan kompetensi dalam merawat pasien gagguan jiwa.}

\section{Tema 4. Dokumentasi Keperawatan}

Perawat RSJ dalam membuat dokumentasi keperawatan menemui beberapa hambatan seperti ketidaklengkapan jenis format SAK yang seharusnya ada, misalnya format di UGD, PICU, Poli Jiwa Anak dan SPO khusus untuk ADL pasien. Hal ini sesuai yang disampaikan oleh partisipan

\section{belum ada...."}

$$
\text { "...format pengkajian di UGD masih }
$$

"...lembar untuk mengkaji jiwa anak masih belum ada..."

".....belum ada standar operasional prosedur untuk ADL pasien..."

“...RS belum ada pijakan paten untuk membuat PICU...instrument untuk keperawatan masih belum ada...."

Format yang digunakan masih dalam proses pengembangan dan evaluasi sehingga terkadang menimbulkan berbagai persepsi yang beragam dan berdampak pada hasil pengisian yang juga beranekaragam.

“....pengisian format pengkajian masih Indonesia raya...."

“....banyak yang tidak mengerti....."

Kondisi tersebut dirasakan menjadi hambatan terutama apabila harus berkomunikasi dengan disiplin ilmu yang lain seperti dengan pihak medis, psikolog maupun okupasi terapis. Ketidaklengkapan juga masih dijumpai pada simbol khusus yang perlu untuk dimodifikasi, misalnya untuk mengkaji masalah nyeri pada pasien gangguan jiwa belum ditemukan model yang tepat.

"...kami masih bingung bagaimana sih triage untuk pasien jiwa...."

“....karena ada akreditasi $R S$, ada yang namanya patient safety...nah...kami belum ada format untuk masalah nyeri pada pasien jiwa....."

Ketidaklengkapan juga termasuk banyak komponen format yang tidak terisi sesuai SPO dan kosong tidak diisi.

$$
\text { “...banyak yang kosong..." }
$$

Pengisian data dokumentasi yang menjadi hambatan dan perlu perhatian khusus adalah validitas data yang dituliskan oleh perawat. Subjektivitas perawat dalam menuliskan evaluasi asuhan keperawatan masih mendominasi sehingga evaluasi yang ada di catatan perkembangan kurang menggambarkan kondisi pasien secara rinci.

\section{Tema 5. Fasilitas}

Fasilitas yang tersedia di RSJ masih menjadi salah satu hambatan yang dirasakan saat perawat akan menerapkan tindakan sesuai dengan SPO yang ada. Seperti SPO untuk menerapkan asuhan keperawatan ADL mandi pada pasien belum ditunjang dengan kelengkapan alat mandi dan fasilitas kebersihan pribadi pasien. Sehingga perawat banyak melakukan modifikasi sesuai dengan ketersediaan yang ada.

“...tidak ada sabun, handuk,..."

".pasien tidak punya alat mandi sendiri...."

\section{Tema 6. Manajemen Ruangan}

Pelaksanaan manajemen di ruangan terutama aspek perencanaan masih menjadi hambatan yang mempengaruhi kinerja asuhan keperawatan pada perawat ruangan. Deskripsi tugas yang tidak jelas terutama dalam pelaksanaan terapi modalitas seperti TAK dan PKRS menimbulkan ketidaknyamanan diantara perawat pelaksana sehingga mempengaruhi kinerja perawat. Selain itu keterbatasan kewenangan perawat untuk melakukan terapi modalitas yang tidak dipayungi oleh kebijakan rumah sakit dan ruangan membuat jenis terapi modalitas yang dapat dilaksanakan baru sebatas TAK dan PKRS.

Aspek pengawasan dalam manajemen ruangan juga menjadi hambatan bagi perawat ruangan dalam menjalankan kompetensi sebagai perawat secara optimal. Kegiatan TAK di ruang rehabilitasi telah dilakukan evaluasi, namun tidak tersampaikan kepada perawat pengelola pasien dan masih kurangnya aspek pengawasan untuk menindaklanjuti hasil evaluasi tersebut membuat kemajuan kemampuan pasien tidak menjadi bagian dari 
evaluasi perawat ruangan. Selain itu sistem reward yang masih belum sesuai dengan kinerja pelaksanaan terapi modalitas seperti TAK, menjadi salah satu alasan perawat untuk tidak bekerja secara maksimal.

\section{Tema 7. Sumber Daya Manusia}

Pelaksanaan kompetensi perawat di RSJ dirasakan menemui hambatan akibat dari keberagaman kondisi sumber daya manusia yang tersedia. Tingkat pendidikan yang bervariasi dari tingkat SPK, DIII, S1 Ners, Magister dan Spesialis mempengaruhi tingkat pengetahuan perawat dalam menerapkan asuhan keperawatan. Perbedaan persepsi masih sering ditemukan dalam hal menentukan diagnosa keperawatan dan menuliskan di format dokumentasi keperawatan. Masa kerja perawat yang juga bervariasi juga menjadi kendala dimana perawat yang masih baru perlu mempelajari kebiasaan yang telah ada dan seni dalam mengatasi permasalahan selama berhadapan dengan pasien gangguan jiwa. Jumlah perawat yang terbatas apabila di bandingkan dengan jumlah pasien, terutama pada shift sore dan malam hari di ruang akut menyebabkan beban kerja perawat yang tinggi. Beban kerja perawat selain akibat dari ketidak seimbangan tersebut juga akibat dari beberapa perawat harus menjabat secara struktural sehingga waktu banyak tersita untuk kegiatan selain di ruang rawat. Selain itu duplikasi beberapa format dokumentasi keperawatan yang harus dilengkapi selama merawat pasien masih menjadi hambatan untuk dapat bekerja secara efisien meskipun beberapa format sudah dimodifikasi dengan bentuk yang lebih sederhana.

\section{Tema 8 Kondisi pasien}

Perawat RSJ dalam menjalankan kompetensi sebagai perawat ruangan juga mendapatkan hambatan akibat dari ketidakpatuhan pasien dalam menjalani program pengobatan di rumah sakit. Kondisi penyakit yang dialami pasien gangguan jiwa membuat pasien memiliki pola pikir, pengendalian emosi dan perilaku yang unik, sehingga perawat harus memiliki kemampuan untuk mengarahkan agar pasien mau mengikuti program terapi yang telah direncanakan bersama tim kesehatan yang lain. Bagi sebagian perawat ketidakpatuhan merupakan tantangan tersendiri, namun tetap menjadi faktor penghambat dalam menjalankan peran dan fungsi sebagai perawat di tatanan RSJ.

\section{PEMBAHASAN}

Kompetensi perawat merupakan tingkatan kinerja (performance) dasar perawat dalam tatanan klinis yang harus dimiliki perawat untuk dapat mengaplikasikan pengetahuan, keterampilan, pengambilan dan penguasaan dalam melaksanakan tugas sebagai seorang perawat. Kompetensi merupakan campuran dari sebuah keterampilan (skill) dengan karakteristik personal (Hye-Won \& Mi-Ran 2014; Mohtashami et al. 2013). Hasil penelitian ini didapatkan beberapa tema terkait dengan kompetensi perawat dalam merawat pasien dengan gangguan jiwa.

\section{Tema 1 Memberikan asuhan keperawatan jiwa}

Asuhan keperawatan adalah tindakan mandiri perawat profesional atau ners melalui kerjasama yang bersifat kolaboratif, baik dengan klien maupun tenaga kesehatan lainnya dalam upaya memberikan asuhan keperawatan yang holistik sesuai dengan wewenang dan tanggung jawabnya pada berbagai tatanan pelayanan termasuk praktik keperawatan individu dan berkelompok (Nursalam, 2003 dalam Muhith, 2015). Hasil penelitian menunjukkan tahapan yang dilakukan dalam melakukan asuhan keperawatan adalah pengkajian, perencanaan, implementasi dan evaluasi. Berdasar Ruang lingkup dan standar praktik keperawatan jiwa, ruang lingkup dan standar praktik dibagi menjadi dua yaitu standar praktik dan standar kinerja professional (professional performance). Standar praktik merujuk pada perawatan yang klien terima dari perawat kesehatan jiwa yang telah teregistrasi dan berdasarkan proses keperawatan. Standar praktik ini meliputi pengkajian, diagnosis, perencanaan, implementasi dan evaluasi (Ballard 2012). Secara garis besar tahapan yang dilakukan sudah sesuai dengan standar praktik keperawatan.

Pengkajian yang dilakukan dibedakan berdasar lokasi yaitu unit Napza, unit anak dan remaja, dan unit geriatri. Masing-masing unit memiliki kekhususan terkait fokus pengkajian yang harus dilakukan. Pengkajian dilakukan perawat untuk mendapatkan data subyektif dan data obyektif termasuk di dalamnya obeservasi klien selama proses wawancara. Pengkajian juga meliputi keluhan utama atau masalah utama, kondisi fisik secara umum, status kesehatan mental dan emosional, riwayat keluarga dan klien, sistem dukungan dalam keluarga, 
kelompok sosial atau komunitas, ADL (Activity Daily Living), kebiasaan kesehatan dan kepercayaan, penyalahgunaan obat, penggunaan obat, hubungan interpersonal, resiko menciderai diri sendiri dan orang lain, koping, kepercayaan dan spiritual dan faktor lain yang mempengaruhi kemampuan klien untuk berfungsi dan berespons pada perawatan (Ballard 2012; Yusuf et al. 2014).

Perencanaan dilakukan secara manual dan terkomputerisasi. Pelaksanaan dengan cara manual memang lebih banyak menghabiskan waktu perawat.Proses implementasi sama-sama menggunakan SP (Strategi Pelaksanaan). Tahapan evaluasi masih ada beberapa hal yang berbeda seperti jenis format evaluasi dan cara mengisi. Hasil penelitian (Rutledge et al. 2013) menyatakan bahwa perawat jiwa mampu melakukan pengkajian pada pasien dengan gangguan jiwa namun tidak percaya diri dalam memberikan intervensi terkait perawatan pasien.

\section{Tema 2 Melaksanakan Standar Prosedur Operasional (SPO)}

Hasil penelitian didapatkan terkait SPO berupa jenis dan pelaksanaan. Jenis SPO berisi tentang asuhan keperawatan pada klien dan beberapa dimodifikasi disesuaikan dengan JCI terkait akreditasi RSJ. Sebuah SPO adalah suatu set instruksi yang memiliki kekuatan sebagai suatu petunjuk atau direktif. Hal ini mencakup proses pelayanan yang memiliki suatu prosedur pasti atau terstandardisasi, tanpa kehilangan keefektifannya. SPO lebih spesifik dari guideline dan dijelaskan dengan lebih detail. SPO menjelaskan kriteria tertentu secara komprehensif tentang langkah-langkah suatu kondisi klinis tertentu (Rao et al. 2011). SPO juga sesuai dengan rumah sakit masingmasing. Setiap sistem manajemen kualitas yang baik selalu didasari oleh SOP yang kemudian disosialisasikan kepada seluruh pihak yang berkompeten untuk melaksanakannya secara rutin. Sosialisasi rutin ini perlu dilakukan agar perawat mengetahui dan mampu mengaplikasikan keterampilannya sesuai SPO yang telah dibuat. SPO diperlukan untuk memastikan bahwa strategi implementasi tidak diabaikan. SPO sebaiknya tersedia di tempat konsultasi pasien, di unit rawat jalan serta di ruang rawat inap serta tempat yang berkaitan dengan perawatan pasien (Rao et al. 2011).
Tema 3 Melakukan terapi modalitas keperawatan jiwa.

Terapi modalitas yang dilakukan jenisnya berupa TAK (Terapi aktivitas Kelompok) dan PKRS (Penyuluhan). Pemberian terapi baik psikofarmaka maupun keperawatan yang tepat dan akurat saja tidaklah cukup pada klien gangguan jiwa, tetapi harus disusul atau bahkan paralel dengan terapi modalitas salah satunya dengan TAK yang secara kontinue dan teratur sampai berfungsinya kembali perilaku normatif yang stabil atau dalam istilah keperawatan perilakunya adaptif (Susana, 2007). Pelaksanaan yang rutin diharapkan akan meningkatkan hasil di pasien. Pelaksana terapi modalitas adalah perawat dan mahasiswa keperawatan. Pelaksana terapi modalitas harus mengetahui proses dan cara pelaksanaan terapi modalitas. Sedangkan ECT dilakukan oleh dokter dengan perawat memberikan asistensi. Waktu pelaksanaan TAK adalah rutin dan terjadwal sedangkan untuk PKRS sesuai dengan kebutuhan klien. Edukasi dan pemberian informasi sudah dilakukan, namun belum berupa psikoterapi. Hal ini berkaitan dengan tingkat pengetahuan perawat dan belum adanya SPO tentang pelaksanaannya. Fasilitas pendukung dalam pelaksanaan terapi modalitas ini berupa leaflet, format dokumentasi dan adanya SPO. Tempat pelaksanaan di dalam rumah sakit dan luar rumah sakit. Metode pemberian berdasarkan dari tujuan, modifikasi, dan bertahap.

\section{Tema 4. Dokumentasi Keperawatan}

Pelaksanaan dokumentasi keperawatan menemui hambatan dalam bentuk ketidaklengkapan format Standar Asuhan Keperawatan (SAK) terutama untuk ruangan dengan karakteristik khusus dan perbedaan persepsi perawat dalam proses pendokumentasian. Dokumentasi keperawatan sangat penting (Iyer \& Comp, 2005) menurut ANA (2000 dalam Nursalam, 2008) dokumentasi merupakan pernyataan bahwa perawat bertanggung jawab dalam melakukan asuhan keperawatan, termasuk dalam mengumpulkan data, mengkaji status kesehatan klien, menentukan rencana asuhan keperawatan, mengevaluasi efektivitas asuhan dan mengkaji ulang serta merevisi kembali rencana asuhan keperawatan. Keberadaan ruangan dengan karakteristik khusus di RSJ seperti ruang gawat darurat(UGD), ruang intensif (PICU), ruang khusus anak, geriatri dan ruang khusus NAPZA, menjadikan perlu untuk dikembangkan format dokumentasi khusus yang menjawab 
kebutuhan tersebut. Format khusus telah dicoba untuk dikembangkan untuk proses Traigedi UGD, namun masih belum jelas untuk mengukur tingkat kegawatan pasien. Format Standar Asuhan Keperawatan di ruang PICU dan poli khusus Anakmasih belum lengkap karena dalam proses pengembangan termasuk cara pengisian dengan benar.

Dinamika perubahan dan perkembangan format dokumentasi menuntut perawat untuk mudah beradaptasi dan segera memahami perubahan tersebut. Kenyataan yang dihadapi belum $100 \%$ format dokumentasi keperawatan tersisi lengkap dan benar, hal tersebut bisa disebabkan oleh perbedaan persepsi perawat dalam pengisian format. Persepsi merupakan proses dimana individu menyeleksi dan memilih aspek khusus dari berbagai situasi yang diterima lalu mengorganisasikannya dalam sebuah pola yang diwujudkan dalam bentuk sikap dan perilaku.Perbedaan informasi yang diterima oleh perawat terkait pengisian format dapat menyebabkan cara pengisian yang berbeda bahkan kebingungan sehingga perawat cenderung tidak mengisi format dengan lengkap. Sehingga setiap perubahan format yang terjadi harus dilakukan secara terencana dan tersosialisasi dengan baik di seluruh personil perawat yang berdinas di ruangan rawat pasien.

Hambatan lain yang ditemukan dalam melakukan dokumentasi adalah validitas data yang dituliskan masih berdasarkan rutinitas.Pelaksanaan asuhan keperawatan masih bersifat rutin sehingga tidak sesuai prioritas masalah dan kebutuhan pasien, sementara evaluasi hanya melakukan evaluasi formatif yaitu evaluasi yang dilakukan setelah dilaksanakan intervensi keperawatan tertentu, namun jarang melakukan evaluasi sumatif sehingga perkembangan atau kemajuan masalah keperawatan tidak ditindaklanjuti. Hal ini sangat prinsip sehingga bila tidak dilakukan akan mempengaruhi kinerja perawat secara keseluruhan dalam merawat pasien. Kinerja perawat khususnya dalam melakukan dokumentasi keperawatan dapat dipengaruhi oleh motivasi(Budiawan, Suarjana \& Wijaya, 2015). Salah satu bentuk motivasi adalah adanya reward dan punisment yang efektif. Situasi yang didapatkan bahwa dokumentasi berdasarkan rutinitas yang telah dilakukan oleh perawat belum bersentuhan dengan aspek motivasi baik yang bersifat reward maupun punishment, sehingga perawat tidak merasakan bahwa dokumentasi yang telah dilakukan merupakan kinerja yang harus diperbaiki. Sehingga kemampuan dokumentasi asuhan keperawatan di RSJ menjadi aspek yang perlu diperhatikan untuk menunjang pencapaian kompetensi perawat dalam melaksanakan asuhan keperawatan secara menyeluruh.

\section{Tema 5. Fasilitas}

Fasilitas yang tersedia di RSJ mesih menjadi salah satu hambatan yang dirasakan saat perawat akan menerapkan tindakan sesuai dengan SPO yang ada. Perawat dalam melaksanakan SPO untuk merawat pasien gangguan jiwa membutuhkan dukungan fasilitas rumah sakit. Fasilitas yang dibutuhkan sebaiknya diidentifikasi dan direncanakan berdasarkan kebutuhan (Depkes RI, 2008). Dalam upaya tersebut dibutuhkan perencanaan dari kepala ruangan untuk menyusun sumber daya yang dimiliki dan dibutuhkan, menentukan strategi sehingga tujuan dapat tercapai(Simamora, 2012). Pelaksanaan kegiatan asuhan keperawatan yang sering terkendala dengan fasilitas ruangan adalah pemenuhan kebutuhan kebersihan diri yang belum dapat dilaksanakan sesuai dengan SPO yang ada. Keterbatasan peralatan mandi seperti sabun, shampo, handuk, sikat dan pasta gigi untuk setiap pasien menstimulasi perawat untuk melakukan modifikasi sehingga kebutuhan tersebut dapat terpenuhi. Kondisi pasien gangguan jiwa yang belum dapat menjaga barang pribadi untuk kebersihan diri menjadi faktor yang harus dipertimbangkan agar kebutuhan kebersihan diri pasien dapat terpenuhi.

\section{Tema 6. Manajemen Ruangan}

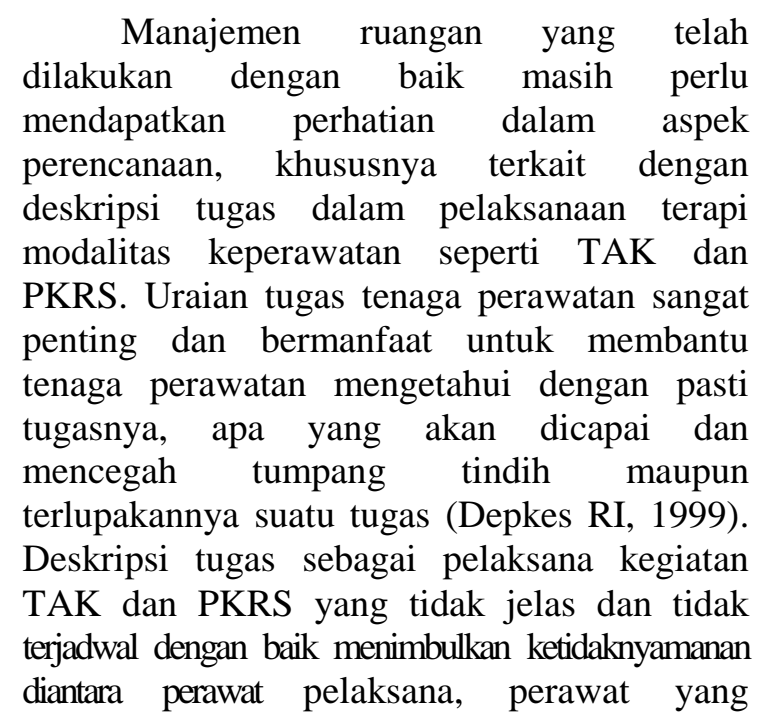


berperan sebagai pemimpin kegiatan berpusat pada beberapa orang saja, sementara dampak finansial dikenakan untuk seluruh perawat. Kondisi tersebut menyebabkan ketimpangan dimana perawat yang tidak bertugas menjadi enggan untuk bergantian menjadi pemimpin TAK maupun PKRS. Situasi tersebut menumbuhkan ketidaknyamanan dan mempengaruhi kinerja perawat.

Selain itu keterbatasan kewenangan perawat untuk melakukan terapi modalitas yang tidak dipayungi oleh kebijakan rumah sakit dan ruangan membuat jenis terapi modalitas yang dapat dilaksanakan baru sebatas TAK dan PKRS. Kepala Ruangan memiliki kewenangan untuk merencanakan dan menentukan jenis kegiatan asuhan keperawatan yang akan diselenggarakan sesuai kebutuhan pasien (Depkes RI, 1999). Kegiatan terapi modalitas merupakan salah satu kebutuhan pasien gangguan jiwa untuk mengembalikan fungsi sosial yang hilang akibat proses penyakit. Beberapa jenis terapi modalitas seperti terapi kognitif, terapi perilaku dan terapi keluarga merupakan kebutuhan bagi pasien gangguan jiwa, dilain sisi adanya pembatasan kewenangan bahwa terapi modalitas tersebut hanya boleh dilakukan oleh Ners Spesialis Jiwa (Konsesnsus konferensi nasional keperawatan jiwa) menjadi kendala karena jumlah Ners Spesialis yang sangat terbatas, terutama di RSJ. Sehingga diperlukan adanya kebijakan rumah sakit yang dapat memfasilitasi kepala ruangan untuk dapat merencanakan kebutuhan terapi modalitas sesuai dengan kebutuhan pasien.

Aspek pengawasan dalam manajemen ruangan juga menjadi hambatan bagi perawat ruangan dalam menjalankan kompetensi sebagai perawat secara optimal. Kepala ruangan berperan dalam melakukan pengawasan dan penilaian pelaksanaan asuhan keperawatan yang telah ditentukan termasuk sistem pencatatan dan pelaporan asuhan keperawatan dan kegiatan yang dilakukan di ruang rawat (Depkes RI, 1999). Kegiatan TAK di ruang rehabilitasi telah dilakukan dan hasil evaluasi kemampuan juga telah didokumentasikan, namun tidak tersampaikan kepada perawat pengelola pasien. Belum efektifnya fungsi pengawasan yang sudah dilaksanakan tidak memberikan dampak bagi perawat untuk menindaklanjuti hasil evaluasi yang telah ada. Kepala ruangan perlu untuk meningkatakan kegiatan supervisi dalam rangka pengawasan sehingga dapat meningkatkan kinerja perawat (Mandagi, Umboh \& Rattu, 2015). Hasil supervisi tersebut dapat diikuti oleh sistem reward dan punisment yeang jelas, sehingga akan dirasakan efektif dan memberikan dampak yang jelas terhadap kinerja perawat ruangan.

\section{Tema 7. Sumber Daya Manusia}

Pelaksanaan kompetensi perawat di RSJ dirasakan menemui hambatan akibat dari keberagaman kondisi sumber daya manusia yang tersedia. Tingkat pendidikan yang bervariasi di RSJ dari tingkat SPK, DIII, S1 Ners, Magister dan Spesialis mempengaruhi tingkat pengetahuan perawat dalam menerapkan asuhan keperawatan. Pendidikan merupakan salah satu kebutuhan dasar manusia yang diperlukan untuk pengembangan diri dimana semakin tinggi tingkat pendidikan, semakin mudah mereka menerima serta mengembangkan pengetahuan dan teknologi (Grossmann, 1999) dan mendukung mendukung produktivitas kerja (Arfrida, 2003). Pencapaian kinerja asuhan keperawatan dengan situasi variasi tingkat pendidikan harus didukung dengan persamaan persepsi terhadap pekerjaan yang akan dilakukan. Hambatan yang ditemui, bahwa perbedaan persepsi masih sering ditemukan dalam hal menentukan diagnosa keperawatan dan cara menuliskan di format dokumentasi keperawatan perlu dijembatani dengan kegiatan penyamaan persepsi serta didukung oleh ketersediaan format dokumentasi dan manual pengisian yang jelas dan terstandar.

Perbedaan dan variasi masa kerja perawat juga mempengaruhi pencapaian kinerja perawat. Pengalaman bekerja menumbuhkan sikap kerja, kecakapan dan ketrampilan kerja yang berkualitas (Harsiwi, 2003) dan mempengaruhi kinerja perawat (Faizin \& Winarsih, 2008). Perawat di RSJ dengan masa kerja kurang dari 3 tahun perlu mempelajari kebiasaan yang telah ada dan seni dalam mengatasi permasalahan selama berhadapan dengan pasien gangguan jiwa. Sementara perawat yang sudah bekerja lebih dari 5 tahun juga perlu mendapatkan informasi terkait penanganan pasien yang efektif berdasar kemajuan informasi dan teknologi, sehingga pelaksanaan asuhan keperawatan pasien gangguan jiwa menjadi lebih optimal.

Ketersediaan jumlah perawat RSJ apabila di bandingkan dengan jumlah pasien, terutama pada shift sore dan malam hari 
menyebabkan beban kerja perawat yang tinggi.Kurniadi (2013) menyebutkan bahwa beban kerja perawat RSJ dipengaruhi oleh kondisi pasien yang selalu berubah, jumlah rerata jam perawatan yang dibutuhkan untuk pelayanan langsung pasien dan dokumentasi asuhan keperawatan serta banyaknya tugas tambahan yang harus dikerjakan oleh perawat sehingga dapat mempengaruhi kinerja perawat tersebut. Ketidakseimbangan jumlah perawat dan pasien yaitumenyebabkan waktu pelayanan langsung ke pasien dirasakan terbatas terutama pada shift sore dan malam hari. Sementara shift pagi, meskipun jumlah perawat yang bertugas lebih banyak, tetapi beberapa perawat harus merangkap sebagai pejabat struktural atau sebagai penanggung jawab dalam kegiatan rumah sakit, sehingga waktu banyak tersita untuk kegiatan selain di ruang rawat. Selain itu duplikasi beberapa format dokumentasi keperawatan yang harus dilengkapi selama merawat pasien, meskipun beberapa format sudah dimodifikasi dengan lebih sederhana, menyebabkan semakin terbatasnya jumlah waktu dalam pelayanan langsung ke pasien. Situasi dan kondisi tersebut dirasakan sebagai beban oleh perawat dan dapat mempengaruhi kinerja perawat dalam melaksanakan asuhan keperawatan pada pasien gangguan jiwa.

\section{Tema 8 Kondisi pasien}

Perawat RSJ dalam menjalankan kompetensi sebagai perawat ruangan juga mendapatkan hambatan akibat dari ketidakpatuhan pasien dalam menjalani program pengobatan di rumah sakit. Kepatuhan merupakan tingkat perilaku klien dalam hal pengobatan yang terkait kemauan mengikuti saran petugas kesehatan (Kyngas, Duffy \& Kroll, 2000). Pasien gangguan jiwa cenderung mengalami ketidakpatuhan terhadap pengobatan yang telah direncanakan oleh perawat, seperti TAK dan Terapi Rehabilitasi saat pasien masih menjalani rawat inap di RSJ. Gangguan jiwa yang bersifat kronis dan membutuhkan pengobatan dalam jangka waktu lama menumbuhkan ketegangan dan tingkat kejenuhan pasien sehingga menyebabkan ketidakpatuhan. Hussar (1995) menjelaskan bahwa pasien dengan penyakit kronis kemungkinan besar menunjukkan sikap kooperatif yang rendah terhadap pengobatan akibat dari perasaan rendah diri akan lamanya pengobatan. Perawat sebagai tenaga kesehatan memiliki peranan penting untuk menjadikan pasien patuh terhadap proses pengobatan. Parashos \& Xiromeritis (2000) menyebutkan $54 \%$ pasien gangguan jiwa patuh terhadap pengobatan akibat adanya hubungan saling percaya antara pasien dan tenaga kesehatan. Hubungan saling percaya dapat dibina melalui kepedulian dan ketulusan perawat dalam memahami kondisi sakit pasien. Selain itu perawat harus memiliki strategi unik untuk menciptakan kondisi yang nyaman dan tidak menimbulkan kejenuhan selama pemberian TAK dan Terapi Rehabilitasi, sehingga pasien mau mengikuti program terapi yang telah direncanakan bersama tim kesehatan yang lain. Perawat harus memiliki persepsi positif terhadap perilaku pasien dan tidak menyerah untuk melaksanakan TAK dan Terapi Rehabilitasi sebagai bagian dari komptensi perawat di tatanan RSJ.

\section{SIMPULAN DAN SARAN}

\section{Simpulan}

Persepsi perawat tentang kompetensi perawat dalam merawat pasien gangguan jiwa adalah melaksanakan asuhan keperawatan, melaksanakan Standar Prosedur Operasional (SPO) di ruangan dan melaksanakan terapi modalitas keperawatan jiwa. Perawat dalam mengaplikasikan kompetensi sebagai perawat jiwa menjumpai hambatan dalam pelaksanaan dokumentasi keperawatan, keterbatasan fasilitas, kurang efektifnya pelakasanaan manajemen ruangan, keterbatasan sumber daya manusia serta kondisi pasien yang dirawat.

\section{Saran}

Temuan penelitian ini dapat dimanfaatkan oleh perawat sebagai bahan untuk mengembangkan desain format dokumentasi pasien gangguan jiwa yang lebih efektif dan diharapkan manajemen rumah sakit untuk lebih memperhatikan aspek pengarahan dan supervisi dalam pelaksanaan kompetensi perawat. Penelitian yang disarankan untuk dikembangkan berdasarkan temuan penelitian adalah melihat hubungan pelaksanaan supervisi keperawatan terhadap peningkatan kinerja dan kepuasan perawat. 


\section{KEPUSTAKAAN}

Arfrida, 2003. Ekonomi Sumber Daya Manusia, Jakarta: Ghalia Indonesia.

Ballard, K.A., 2012. Issues and Trends in Psychiatric Mental Health Nursing. In Psychiatric Nursing. Jones and Barlett Publisher, pp. 2138. Available at: http://nursing.jbpub.com/book/psychiatric.

Budiawan, I.N., Suarjana, I.K. \& Wijaya, I.P.G., 2015. Hubungan Kompetensi , Motivasi dan Beban Kerja dengan Kinerja Perawat Pelaksana di Rumah Sakit Jiwa Provinsi Bali. Public Health and Preventive Medicine Archive, 3(2).

Depkes RI, 1999. Pedoman Uraian Tugas Tenaga Keperawatan di Rumah Sakit, Jakarta: Direktorat Pelayanan Medik.

Depkes RI, 2008. Standar Pelayanan Minimal Rumah Sakit, Jakarta: Departemen Kesehatan Republik Indonesia.

Faizin, A. \& Winarsih, 2008. Hubungan Tingkat Pendidikan dan Lama Kerja Perawat dengan Kinerja Perawat di RSU Pandan Arang Kabupaten Boyolali. Berita Ilmu Keperawatan, 1(3), pp.137-142.

Grossmann, M., 1999. The Human Capital Model of The Demand for Health, Cambridge: National Bureau of Economic Research.

Harsiwi, A.M., 2003. Hubungan Kepemimpinan Transformasional dan Karekteristik Personal Pemimpin. Journal Bisnis dan Ekonomi, 5(1).

Hussar, S.A., 1995. Patient Compliance in Remington: The Science and Practice of Pharmacy 2nd ed., Philadephia: The Philadelphia Collage of Pharmacy and Science.

Hye-Won, K. \& Mi-Ran, K., 2014. Nursing Competency as Experienced by Hospital Nurses in a Clinical Nursing Unit. International Journal of Bio-Science and BioTechnology, 6(4), pp.235-244.

Iyer, P.W. \& Comp, N.H., 2005. Dokumentasi Keperawatan: Suaru Proses Pendekatan Proses Keperrawatan 3, ed., Jakarta: EGC.
Kurniadi, A., 2013. Manajemen Keperawatan dan Prospektifnya: Teori, Konsep dan Aplikasi, Jakarta: Badan Penerbit FKUI.

Kyngas, H., Duffy, M.E. \& Krol, T., 2000. Review Conceptual Analysis of Compliance. Journal of Clinical Nursing, 5(3).

Mandagi, F.M., Umboh, J.M.L. \& Rattu, J.A.M., 2015. Analisis Faktor-Faktor yang Berhunungan dengan Kinerja Perawat dalam Menerapkan Asuhan Keperawatan di RSU Bathesda GMIM Tomohon. Jurnal eBiomedik, 3(3).

Mohtashami, J. et al., 2013. Competency-based curriculum education in mental health nursing. Open Journal of Nursing, 3, pp.545-551. Available

at: (http://www.scirp.org/journal/ojn/).

Muhith, A., 2015. Pendidikan Keperawatan Jiwa: Teori dan Aplikasi M. Bendetu, ed., Yogyakarta: CV Andi Offset (Penerbit Andi).

Nursalam, 2008. Proses Dan Dokumentasi Keperawatan: Konsep dan Praktik, Jakarta: Salemba Medika.

Parashos, I.A. \& Xiromeritis, K.O., 2000. The Problem of Non-Compliance in Skizofrenia: Opinion of Patients and Their Relatives. Journal of Clinical Nursing, 4(3).

Rao, T.S.S., Radhakrishnan, R. \& Andrade, C., 2011. Standard operating procedures for clinical practice. Indian Journal of Psychiatry, 15(1), pp.1-3.

Rutledge, D.N. et al., 2013. Hospital Staff Nurse Perceptions of Competency to Care for Patients With Psychiatric or Behavioral Health Concerns. Journal for Nurses in Professional Development, 29(5), pp.255-262. Available at: www.jnpdonline.com.

Simamora, H., 2012. Manajemen Sumber Daya Manusia 3rd ed., Bandung: Pustaka Setia.

Yusuf, A., Fitryasari, R. \& Nihayati, H.E., 2014. Buku Ajar Keperawatan Jiwa 1st ed., Surabaya: Salemba. 